\title{
Computer Conservation Society (CCS) - Its Story and Experience
}

\author{
Roger Johnson \\ Birkbeck University of London, Dept. of Computer Science, UK \\ r.johnson@bcs.org.uk
}

\begin{abstract}
There were three main motivational drivers for founding the Computer Conservation Society as a joint co-operative venture of the Science Museum and the British Computer Society. These were the:

- restoration to working order of historic computing machines for public display;

- provision of an organisational context for the expertise of computer designers and practitioners with unique knowledge of historic machines;

- $\quad$ capture, documentation and preservation of computing knowhow.

Computer restoration, public display, and the notion of a 'club' were essential features of the original conception. Preservation and social utility were inseparably joined from the start. This paper reviews nearly 25 years of activity in pursuit of these aims.
\end{abstract}

Keywords: Computer Conservation Society, Resurrection, computer restoration.

\section{Introduction}

This paper recounts briefly the founding of the Computer Conservation Society (CCS) and the activities that have developed over the quarter of a century since then. The paper lists the projects that the CCS has undertaken and a number of these are described in detail in other papers submitted to this book. The paper concludes by looking at the key factors in making the CCS the world's largest computer history society and the leading source of expertise in the restoration of historic computers and the construction of replicas.

\section{Foundation}

The Computer Conservation Society (CCS) was founded in 1989. To explain why the CCS came to be founded at that time there is no better source than a CCS promotional leaflet prepared by Chris Burton [1].

It was a time when the computer industry had existed for about half a century, and when many people had spent a professional lifetime in the industry. The industry had matured, but was still poised for ever greater technological and social changes as it had been from its beginnings in the 1940s. It was time to take stock and reflect on the extraordinary 
developments to date, and in particular, to be concerned that many of the pioneering people and hardware and software were fast disappearing.

At the same time, many computer professionals were finding themselves retired or otherwise at the end of direct involvement in the industry, yet with energy to spare and interest in their earlier systems. Some had approached the Science Museum, for example, asking whether their abilities and interests could be harnessed to helping to preserve old systems. This coincided with a perception by the Museum that it had artefacts, but limited expertise to do other than prevent deterioration - in particular it was not able to present their technological and historical significance.

Thus the Society came into existence as a way of structuring and channelling these complementary interests.

The story of how it was founded is recorded in two early issues of Resurrection [2], the bulletin of the CCS. Nick Enticknap, the first Editor of Resurrection, recounts in the first issue of Resurrection that the CCS "is the brainchild of Doron Swade, Curator of Computing at the Science Museum" [3]. In Issue 7, Doron Swade himself recounts that:

The origins of the Society are within easy recall. As curator of computing I paid innumerable site visits in response to offers of obsolete equipment from potential donors faced with having to dispose of cherished machines. Visiting these doomed equipments and engaging with their minders made it evident that there was expertise, goodwill and enthusiasm that lacked organised expression. The Computer Conservation Society was conceived to provide a social and organisational focus for this community of isolated practitioners who wished to share, contribute, impart knowledge and skill, or simply participate in a continuing way in an activity that was meaningful to them. [4]

The two people he met at the British Computer Society were its Technical VicePresident, Roger Johnson, the author of this paper, and Tony Sale, the BCS' Technical Director. Tony Sale was an extraordinary "electronics polymath" but not a public personality at that time. He had served in the Royal Air Force working on radar, the UK security service MI5 specialising in wireless interception and run a computer bureau and software house. Roger Johnson was a computer science academic with a lifelong love of industrial archaeology. Tony Sale and the author were immediate converts to the cause and swiftly organised the establishment of the Computer Conservation Society as a Specialist Group (a special interest group) of the BCS. As a Specialist Group of the British Computer Society, it has benefited from BCS support, as well as from the status accorded by the Royal Charter. The association with the Science Museum provides access to the Museum's inventoried artefacts, as well as the generous provision of facilities for our meetings. In consequence, the CCS describes itself as being founded as a co-operative venture between the Science Museum and the BCS.

These formalities were quickly followed by the creation of an initial committee comprising Doron Swade, Tony Sale and the author together with two BCS Past 
Presidents who were both computer pioneers. The first public meeting attracted 67 people. Most of the major threads of the CCS' activities were present almost from the beginning. At the first meeting five working parties were created each focussed on different pieces of computing equipment. A lecture programme was inaugurated and shortly afterwards the first issue of the CCS bulletin called Resurrection appeared.

From the beginning, the Society was fortunate in attracting a number of pioneers of the industry, many of whom subsequently served as officers, committee members or project team members. The total membership is presently about seven hundred, distributed all over the UK and the world, and of this number about $15 \%$ are active and attend meetings etc.

In 1993, in recognition of the important early work done in the Manchester and north-west Midlands area, the North West Group of the CCS was created, based in Manchester, and with a strong connection with the Manchester Museum of Science and Industry. This group has its own officers and committee and runs a thriving local series of meetings and other work.

\section{Guiding Principles}

Membership of the CCS has always been open to anyone who is interested in the history of computing whether or not they are a member of BCS [5]. There is no qualification required other than an expression of that interest! Furthermore, there is no membership fee, though members receive an annual invitation to make voluntary donations to the "rescue fund" which is used to support CCS projects when urgent expenditure has to be incurred, for example to safeguard an early computer. As mentioned, the Society benefits from support provided by the museums and the BCS. In addition, the CCS gratefully acknowledges that support, financial and in kind, for projects from a number of corporate bodies.

Another important policy that has emerged is that the CCS should not own any computers. A decision was made in the early days that the CCS would not acquire any computers or peripheral equipment. It was clear to the committee that computers should be owned by museums and the role of the CCS was to assist museums in restoring computers to a suitable condition for display or, when appropriate, for demonstration and constructing replicas. The rationale was based on several considerations. Firstly, the CCS was a group of volunteers with no legal status beyond that provided by the BCS and no long term guarantee of existence and hence no ability to own assets for the long term. Secondly the CCS wanted to work with any museum which had computing equipment and having our own equipment could potentially give rise to conflicts of interest. The one exception to the policy, for historic reasons, is the Bombe Rebuild which is formally owned by the BCS (as the CCS parent body) and is the subject of a long term agreement with Bletchley Park for its display there. Numerous minor issues over the years, such as securing public liability and other insurance, illustrate how many hours of volunteer time can be consumed on necessary but unrewarding matters. These are much better left to the professional staff of museums! 


\section{$4 \quad$ Bletchley Park}

The CCS has always had strong links with Bletchley Park. Tony Sale led the early attempts to save it for the nation when it was threatened with demolition. The links continued as Tony built his replica of Colossus and John Harper and his team build the Bombe replica. As the governance of Bletchley Park evolved the links changed but the CCS remained firmly committed to ensuring that these two iconic replicas continue to be demonstrated as a tribute to the thousands who worked at Bletchley Park during the war.

Around these two projects various other projects sprang up. As the number of projects grew the work has been incorporated into The National Museum of Computing (TNMoC) [6]. This is a legally distinct body from the Bletchley Park Trust although they work closely together to provide an integrated attraction for visitors. TNMoC now has the largest collection of functional historic computers in Europe, many of which have been restored or built as CCS projects.

\section{$5 \quad$ Other Achievements}

Following his death in 2011, the CCS was very pleased to establish, with support from Google, the Tony Sale Award [7] to recognise singular engineering achievements in the area of computer conservation achievements in the growing area of computer conservation. The first Award was presented at a ceremony held October 2011. The winning project is the Ferranti Mark 1 LoveLetters, reconstruction of software for text generation submitted by Dr David Link from Cologne.

In 2012 four members of the CCS co-authored a book entitled Turing and his Contemporaries [8] as part of the celebrations of the centenary of Alan Turing's birth. All the proceeds from the book go to the CCS Rescue Fund and so far amount to around $£ 4,000$.

\section{$6 \quad$ Working Parties}

From its creation the most visible part of the CCS' work has been its support for the restoration of computers and their subsequent demonstration and its support for groups wishing to build replicas. Details of all the current Working Parties are listed on the CCS website at http://www.computerconservationsociety.org/wg.htm. Current projects are:

\begin{tabular}{|l|l|l|}
\hline Manchester Baby & $\begin{array}{l}\text { The project built, and now demonstrates } \\
\text { and maintains a replica of the Small- } \\
\text { Scale Experimental Machine (SSEM) - } \\
\text { the world's first computer. }\end{array}$ & $\begin{array}{l}\text { Museum of Science and Industry, } \\
\text { Manchester }\end{array}$ \\
\hline Pegasus & $\begin{array}{l}\text { The Pegasus computer on display at the } \\
\text { Science Museum was, for many years, } \\
\text { the oldest extant working electronic } \\
\text { computer in the world. Members of the } \\
\text { CCS maintain and operate the Pegasus - } \\
\text { and expect to resume regular fortnightly } \\
\text { at the museum in the near future. }\end{array}$ & Science Museum, London \\
\hline
\end{tabular}




\begin{tabular}{|c|c|c|}
\hline Bombe Rebuild & $\begin{array}{l}\text { The rebuilt machine is now operational } \\
\text { and can be seen at Bletchley Park. }\end{array}$ & Bletchley Park \\
\hline ICT 1301 & $\begin{array}{l}\text { An original } 1961 \text { machine is being } \\
\text { brought back to life. It has recently been } \\
\text { moved into store with help from the CCS } \\
\text { Rescue Fund from private premises in } \\
\text { Kent. }\end{array}$ & $\begin{array}{l}\text { National Museum of Computing, } \\
\text { Bletchley Park (currently in store } \\
\text { off-site) }\end{array}$ \\
\hline Elliott 401 & $\begin{array}{l}\text { The CCS is restoring an Elliott } 401 \\
\text { computer. This machine is not available } \\
\text { to be seen by the general public at the } \\
\text { moment. }\end{array}$ & $\begin{array}{l}\text { Science Museum, London } \\
\text { (currently in store) }\end{array}$ \\
\hline Elliott & $\begin{array}{l}\text { This team is responsible for a collection } \\
\text { of Elliott } 803,903 \text { and } 905 \text { computers. } \\
\text { The TNMOC } 803 \text { and } 903 \text { machines can } \\
\text { be seen working most weekends. }\end{array}$ & $\begin{array}{l}\text { National Museum of Computing, } \\
\text { Bletchley Park }\end{array}$ \\
\hline $\mathrm{DEC}$ & $\begin{array}{l}\text { The DEC project team is currently } \\
\text { restoring a desktop 'straight' PDP8, the } \\
\text { PDP11 Blacknest system, and } \\
\text { demonstrates the last remaining PDP11 } \\
\text { based air traffic control system from } \\
\text { LATCC, West Drayton. }\end{array}$ & $\begin{array}{l}\text { National Museum of Computing, } \\
\text { Bletchley Park }\end{array}$ \\
\hline Hartree Analyser & $\begin{array}{l}\text { The project is restoring the pre-World } \\
\text { War II differential analyser to } \\
\text { demonstration condition. }\end{array}$ & $\begin{array}{l}\text { Museum of Science and Industry, } \\
\text { Manchester }\end{array}$ \\
\hline $\begin{array}{l}\text { Harwell Computer } \\
\text { (also known as the } \\
\text { WITCH computer }\end{array}$ & $\begin{array}{l}\text { This project team has successfully } \\
\text { restored the original Harwell Computer } \\
\text { to working order making it the world's } \\
\text { oldest working computer. The team is } \\
\text { now maintaining it for demonstration. }\end{array}$ & $\begin{array}{l}\text { National Museum of Computing, } \\
\text { Bletchley Park }\end{array}$ \\
\hline ICL 2966 & $\begin{array}{l}\text { This project team is restoring an ICL } \\
2966 \text { mainframe to demonstration } \\
\text { condition. }\end{array}$ & $\begin{array}{l}\text { National Museum of Computing, } \\
\text { Bletchley Park }\end{array}$ \\
\hline EDSAC replica & $\begin{array}{l}\text { This is latest project and is building a } \\
\text { replica of the original Cambridge } \\
\text { University EDSAC computer. }\end{array}$ & $\begin{array}{l}\text { National Museum of Computing, } \\
\text { Bletchley Park }\end{array}$ \\
\hline Analytical Engine & $\begin{array}{l}\text { This project aims to fulfil Charles } \\
\text { Babbage's plans by constructing his } \\
\text { Analytical Engine. }\end{array}$ & \\
\hline \begin{tabular}{|l|} 
Software \\
Conservation
\end{tabular} & $\begin{array}{l}\text { The mission is the preservation of } \\
\text { historic software in machine readable } \\
\text { form, ideally along with execution } \\
\text { capability. The focus is on long-term } \\
\text { preservation rather than special effects } \\
\text { on a PC. }\end{array}$ & \\
\hline $\begin{array}{l}\text { Our Computer } \\
\text { Heritage }\end{array}$ & $\begin{array}{l}\text { This is a substantial online database } \\
\text { which collects and disseminates } \\
\text { information on all British manufactured } \\
\text { computers, currently built up to } 1965 \text {. }\end{array}$ & www.ourcomputerheritage.org \\
\hline
\end{tabular}




\section{$7 \quad$ Lecture and Seminar Programme}

Each year the CCS organises a series of monthly lectures from the autumn until early summer at the Science Museum. The lectures cover a wide range of topics covering hardware, systems software and applications. Every lecture has been recorded initially in audio and more recently on video.

There is a separate programme of lectures in the North West Group run at the Museum of Science and Industry in Manchester.

\section{8 "Resurrection"}

The CCS's quarterly bulletin sent free to all members funded from an annual BCS grant. It is a unique chronicle of the CCS' progress both of, and by, computer pioneers and practitioners providing members with news, articles, transcripts of lectures and other material in a 32-page A5 format. All issues of Resurrection are available online [9].

\section{Two Key Challenges}

\subsection{Sustaining the Skills for the Future}

Not surprisingly from the beginning, the CCS has repeatedly asked itself what it was doing and how it was doing it. In the first issue of Resurrection, Doron Swade wrote an article [10] discussing how the activities of the CCS and Science Museum "overlap, complement and extend". The close ties with the Science Museum have always ensured that CCS volunteers are well versed in curatorial standards before they are allowed to work on computers in the care of any museum. This has proved essential in building lasting relationships between the CCS and a range of museums.

One of the key drivers for the Science Museum was the realisation that museum staff faced a problem an order of magnitude greater in restoring a computer to demonstration condition compared to that of staff working on automotive or steam powered exhibits. Beginning in 1989 meant that for almost all the restored machines, volunteers could be found with experience of building or maintaining the computers. The CCS has concerned itself for some time about how to ensure that these skills are passed on to another generation of volunteers. Initial experience with students proved disappointing as the student population turns over quickly and once graduated most move away and take on major commitments. Consequently it appears likely that volunteers may be drawn from all age groups but that many, just because of having the time available, may be retired.

In reflecting on this in the specific context of and the demonstrations of the Science Museum Pegasus, discussions within the museum have identified three activities for volunteers, each of which requires different expertise and training. The three roles are, firstly, interpretation carried out by someone trained to explain the artefact to a group of visitors, secondly, demonstrators who have been trained to run demonstrations of 
the machine to accompany the interpreter's talk and finally a systems engineer who has the skills to maintain the computer including diagnosing and rectifying faults. While there is no reason why one person should not acquire the skills to fulfil all three roles, experience suggests that different personalities and backgrounds often lead to one role rather the others.

\subsection{Connecting with Visitors}

Although one of the first working parties was devoted to software preservation the awareness of the importance of this activity has steadily grown over the years. Naturally early work concentrated on restoring early computers to working condition. However old machines returned to running order and were placed on display the challenge arose of how to construct a meaningful narrative for the visitor. In a recent issue of Resurrection, Kevin Murrell discusses the issue of what software to run [11]. A computer is a complex artefact often running in a specialised application domain. Added to this must be added the differing interests of visitors from those who take a casual look, those who will stay for a short demo and finally those who are seeking an in depth explanation. This is a routine challenge for a museum but for many industrial archaeological artefacts the public have significant prior knowledge. However computers have three distinct aspects - hardware, systems software and an application domain. As Kevin notes in the paper, the opportunity to obtain a computer from a visually exciting and accessible application with its supporting software and data is likely to be very rare. However the air traffic control system on display at the National Museum of Computing ticks all the boxes. However it is clear that for the future compelling displays are important to providing visitors with a strong narrative.

It follows from Kevin's observations that many visitors seeing a visually attractive demonstration are primarily focussed on the output devices and the hardware and system software are largely invisible. Consequently it can be argued that many visitors are indifferent to whether the output is being produced by historic hardware, a replica or software emulation. Indeed one of the benefits of computing is that it is possible to write software today to demonstrate the capabilities of a historic computer. The blending of original, replica and emulated machines with original and modern software offers many creative challenges for the designers of future computing exhibits in our museums.

\section{Factors for the CCS' Success}

As it approaches its $25^{\text {th }}$ anniversary, the CCS remains a cheerful, energetic and slightly renegade outfit. Its committees and working parties are populated by passionate volunteers dedicated to preserving computing history. So what are the key factors in its success?

a. IT Industry Legacy - The UK had a multiplicity of hardware manufacturers for the first 20 years of the computer industry. This produced a range of 
computers around which to work. In turn this led to skilled engineers experienced in supporting these machines who were enthusiastic in later life to resume working with their early computers.

b. Available artefacts - Museums in the UK, supplemented by companies and individuals, retained numerous early computers and years later as opportunity offered were keen to see them displayed and when appropriate restored to demonstration condition. The museums became keen to have examples of computers on display and sometimes being demonstrated.

c. Institutional support - Restoring computers or building replicas needs a significant amount of secure space. Initially the Science Museum provided space to restore their Pegasus until it was placed on display. They also provide space today in their London store for work on the Elliott 401. Without such space the work would not be possible. CCS has also been grateful to both the University of Manchester for providing space for the building of the Manchester Baby replica and subsequently to the Museum of Science and Industry for displaying it prominently in their main entrance and also for supporting other restoration work in Manchester. Finally the emergence of the National Museum of Computing located at Bletchley Park provides substantial display space to display historic artefacts and also work space for current projects.

All these centres enable volunteers to support one another and to share expertise which is vital to sustaining volunteer communities. They foster a vital "club" spirit for the volunteers.

Finally the support of the BCS has been important funding in supporting its activities each year. The BCS provides a small operating grant and also meets the significant costs of producing and distributing Resurrection. They also provide free access to substantial administrative facilities including a membership database, use of their website and email facilities.

\section{Future}

Sir Maurice Wilkes remarked at an early meeting that he thought the CCS would last about two years and then run out of things to do. Happily Sir Maurice lived long enough to be able to enjoy reminding us of this comment and his pleasure at attending lectures on a growing range of new topics each year.

In many ways this is mirrored in the evolution of the CCS' published Aims. The original version from 1989 was to:

- promote the conservation of historic computers,

- develop awareness of the importance of historic computers, and

- encourage research on historic computers.

Today, while the first two aims remain essentially the same while the third aim has been supplemented and expanded reflecting the way the CCS' understanding of its role has evolved to: 
- promote the conservation of historic computers and to identify existing computers which may need to be archived in the future,

- develop awareness of the importance of historic computers,

- develop expertise in the conservation and restoration of historic computers,

- represent the interests of Computer Conservation Society members with other bodies,

- promote the study of historic computers, their use and the history of the computer industry,

- publish information of relevance to these objectives for the information of Computer Conservation Society members and the wider public.

There are always more computers and their applications to display. Today's systems are tomorrow's history! The understanding which the CCS volunteers have developed in demonstrating working computer systems has highlighted the importance of identifying examples of contemporary systems for museums to acquire. This has to involve acquiring as much of the working environment, application software and peripherals as well as the core system, so as to provide accessible exhibits for museum visitors.

Public interest in the development of information technology continues to grow and the CCS is committed within its resources to responding to that interest by acquiring and disseminating information about information technology.

Through their work the CCS membership promotes awareness of the unique transformative power of IT upon civil society worldwide both as a tribute to those who have gone before and to fire the imaginations of those who will come after us.

Acknowledgments. I would like to thank colleagues in the BCS Computer Conservation Society for their help in preparing this paper. However, the opinions in this paper are those of the author and this is not an official CCS paper. Any errors are solely the fault of the author.

\section{References}

1. The Computer Conservation Society. Promotional leaflet prepared by Chris Burton, Private correspondence with author (2003)

2. Resurrection - all issues available online at, http: / / www. computerconservationsociety.org/resurrection.htm

3. Enticknap, N.: Computer Conservation Society - birth. Resurrection 1(1), 5 (1990)

4. Swade, D.: The CCS and the Science Museum - what now? Resurrection (7), 7 (1993)

5. CCS Membership, http: / /www. computerconservationsociety.org/Joining.htm

6. The National Museum of Computing, http://www. tnmoc.org/

7. Tony Sale Award, http: / /www. sale-award.org/

8. Lavington, S. (ed.): Turing and his contemporaries - Building the world's first computers. Published by BCS (2012) ISBN 978-1-906124-90-8

9. Resurrection, http: / /www. computerconservationsociety.org/resurrection.htm

10. Swade, D.: Computer Conservation and Curatorship. Resurrection 1(1), 8 (1990)

11. Murrell, K.: Demonstrating Restored and Replica Computers. Resurrection (60), 18-22 